\title{
COMPARISON OF INDOOR AIR TEMPERATURE AND OPERATIVE TEMPERATURE -DRIVEN HVAC SYSTEMS BY MEANS OF THERMAL COMFORT AND ENERGY CONSUMPTION
}

Cihan TURHAN*, Department of Energy Systems Engineering, Atılım University, Turkey, cihan.turhan@atilim.edu.tr

(iD https://orcid.org/0000-0002-4248-431X)

Received: 23.01.2020, Accepted: 17.06.2020

*Corresponding author

Research Article

DOI: $10.22531 /$ muglajsci.679256

\begin{abstract}
The main purpose of Heating, Ventilating and Air-Conditioning (HVAC) systems is to satisfy thermal comfort for the occupants. Conventionally, HVAC systems adjust set-temperature to achieve thermal comfort by continuously measuring indoor air temperature of the environment. However, ASHRAE 55, a standard of acceptable thermal environments, offers to use acceptable ranges of operative temperatures in air-conditioned buildings. Considering operative temperature is a function of indoor air temperature and mean radiant temperature, set-temperature of HVAC system can be controlled by using operative temperature to satisfy neutral thermal comfort for the occupants. This study compares thermal comfort and energy consumption of two exactly same HVAC systems which are operated based on indoor air temperature and operative temperature, respectively. Two office rooms with same architectural configurations -which are located in a university-Ankara-Turkey- were selected as a case study. The HVAC systems were operated based on indoor air temperature and operative temperature, respectively, at the same time and occupancy schedules. The results showed that operative temperature driven controlled HVAC system achieves better thermal comfort while slightly increasing energy consumption. The main findings of this study would be useful not only to design energy-efficient HVAC systems but also create more comfortable environments.

Keywords: Thermal Comfort, Operative Temperature, HVAC System Control, Energy Consumption

\section{İÇ HAVA SICAKLIĞI VE OPERATİF SICAKLIK BAZLI HVAC SISSTEMLERINNINN ISIL KONFOR VE ENERJİ TÜKETIMİ BAKIMINDAN KARŞILAŞTIRILMASI}

Özet

Isıtma, Soğutma ve Havandırma (HVAC) sistemlerinin ana amacı kullanıcılar için ısıl konforu sağlamaktır. Geleneksel olarak, HVAC sistemleri ısıl konforu sağlayabilmek için iç hava sıcaklığını sürekli ölçerek set-değerlerini ayarlar. Ancak, bir kabül edilebilir ısıl çevre standardı olan ASHRAE 55, iklimlendirilmiş binalar için operatif sıcaklık kabül aralıklarını kullanmayı önermektedir. Operatif sıcaklığın, iç hava sıcaklığı ve ortalama radyant sıcaklığın bir fonksiyonu olduğu düşünülürse, kullanıcıların nötr ısıl konforunun sağlanması için HVAC sistemlerinin set-değerleri operatif sıcaklı̆ga göre kontrol edilebilir. Bu çalışma, biri operatif sıcaklık ve diğeri iç hava sıcaklı̆̆ı bazlı aynı özellikteki iki oda bulunan aynı özellikteki iki HVAC sistemini ısıl konfor ve enerji tüketimi bakımından karşılaştırmaktadır. Örnek çalışma olarak, Ankara-Türkiye'de bulunan aynı mimari özelliklerdeki iki ofis odası seçilmiştir. HVAC sistemleri aynı zamanda ve aynı doluluk oranlarında ayrı ayrı operatif sıcaklık ve iç hava sıcaklığı bazlı kontrol edilerek çalıştırılmıştır. Sonuçlar, operatif bazlı HVAC sisteminin enerji tüketimini az da olsa arttırdığını fakat daha iyi ısıl konfor sağladığını göstermiştir. Bu çalışmanın sonuçları sadece enerji verimli HVAC sistemleri tasarlamak için değil, daha konforlu ortamlar yaratmak açısından da yol gösterici olacaktır.

Anahtar Kelimeler: Isıl Konfor, Operatif Sıcaklık, HVAC Sistem Kontrolü, Enerji Tüketimi

Cite

Turhan, C., (2020). “Comparison of indoor air temperature and operative temperature -driven HVAC systems by means of thermal comfort and energy consumption" Mugla Journal of Science and Technology, 6(1), 156-163.

\section{Introduction}

Heating, Ventilating and Air-Conditioning (HVAC) systems maintain thermal comfort for occupants in buildings [1]. However, measuring or estimating the thermal comfort is usually difficult since the concept depends on multi-parameters. Standards on the thermal comfort such as ASHRAE 55 [1] and ISO 7730 [2] still use Fanger's Predicted Mean Vote (PMV) index which lays on six parameters (indoor air temperature $\left(\mathrm{T}_{\mathrm{i}}\right)$, relative humidity $(\mathrm{RH})$, air velocity $\left(\mathrm{v}_{\mathrm{a}}\right)$, mean radiant temperature (MRT), clothing value (clo) and metabolic rate (met)) [3]. PMV index uses a thermal scale which is 
between -3 (cold) and +3 (hot). The zero value of PMV is called as neutral thermal comfort which means that the occupants feel fully-comfortable in the environment [1]. However, in ASHRAE 55, a range of \pm 0.5 of PMV is also accepted as comfortable in a conditioned environment which is the aim to be achieved by an HVAC system.

Thermostats generally measure indoor air temperature of the thermal environment in order to control HVAC system operations [4]. However, thermal comfort is a multi-parameter concept where other parameters should be taken into consideration. Operative temperature (OT) (also called as resultant temperature) can be counted as one of significant factor on the thermal comfort. OT is the combination of MRT, $\mathrm{T}_{\mathrm{i}}$ and $\mathrm{V}_{\mathrm{a}}$, and therefore highly affects thermal comfort of occupants [5-7]. Many studies measured OT instead of $\mathrm{T}_{\mathrm{i}}$ in their thermal comfort researches [8-11]. For instance, Kwok and Chun [8] investigated thermal comfort levels in air-conditioned and natural ventilated Japanese schools. OT was calculated by measuring MRT, $\mathrm{T}_{\mathrm{i}}$ and $\mathrm{v}_{\mathrm{a}}$ of the environment and the authors concluded that thermal responses of the students were different in air-conditioned schools due to the expectations from HVAC system and availability of control. In another study by Nicol and Humpreys [9], a strong relationship was found between OT and thermal comfort since OT represents both $\mathrm{T}_{\mathrm{i}}$ and temperature of the walls. The authors also concluded that OT is highly dependent on the outdoor temperature $\left(\mathrm{T}_{\mathrm{o}}\right)$.

On the other hand, energy consumption of HVAC system can be decreased by using proper control methods [12]. Adjusting inaccurate set-temperature for HVAC system lead higher energy consumption in buildings. For instance, Kusiak et al. [13] investigated the relationship between the control settings and energy consumption of the HVAC system. The HVAC system was controlled only according to the $\mathrm{T}_{\mathrm{i}}$ and the authors found that a $7.6 \%$ of energy could be saved by optimization of HVAC control. However, the study indicated that other uncontrollable parameters such as $\mathrm{T}_{0}$ and MRT should be taken into account in the studies. To this aim, Jain et al. [14] suggested to use OT-driven control in HVAC systems of highly-glazed buildings. The authors concluded that high temperature of window panes in summer highly affects energy consumption. However, thermal comfort of the occupants was not investigated in the study. Olesen et al. [15] simulated three different HVAC systems including fan-coil system and floor and ceiling based radiant systems by regulating $\mathrm{T}_{\mathrm{i}}$ and OT. The results showed that the use of OT-driven control in fancoil system achieved better thermal comfort. However, the results were based on simulation, therefore experimental results were not given in the study. Similarly, Wang et al. [16] suggested that $\mathrm{T}_{\mathrm{i}}$-driven thermostat control be used in fan-coil system while OTdriven thermostat control could be preferred in radiant system in offices according to the simulation results. In addition, Niu and Burnett [17] used OT instead of $\mathrm{T}_{\mathrm{i}}$ in building energy simulation programs. The authors concluded that there was a huge difference in energy consumption between OT and $\mathrm{T}_{\mathrm{i}}$-based simulations. On the other hand, Turhan and Akkurt [18] investigated thermal comfort of occupants in an office in Mediterranean climate zone by using $\mathrm{T}_{\mathrm{i}}$-based controller. Although an experimental study was conducted in an office environment, the effect of OTdriven controller on thermal comfort was not evaluated. Even though HVAC systems are typical non-linear multiparameter systems, most of HVAC system adjust settemperature according to the $\mathrm{T}_{\mathrm{i}}$. In addition, temperature of the walls highly affects thermal comfort of occupants due to the radiation between human body and wall surfaces. For this reason, measuring OT instead of $\mathrm{T}_{\mathrm{i}}$ can be a better solution to achieve better thermal comfort However, energy consumption should also be investigated not only with simulations but also with insitu measurements.

Up to now, there exists a few simulation studies which compare OT and $\mathrm{T}_{\mathrm{i}}$-operated HVAC system controllers [14-18] according to the author's knowledge. This study distinguishes from previous studies by comparing OT and $\mathrm{T}_{\mathrm{i}}$-driven HVAC systems in terms of both thermal comfort and energy consumption in a real environment. For this aim, two office rooms which have same architectural configurations, are operated with two same HVAC systems, one is $T_{i}$-driven (in Office $A$ ), and another is OT-driven (in Office B) HVAC systems. Each office room is occupied with one occupant by using same occupancy schedules.

\section{Case Building}

The case building is located in Atılım University campus Ankara/Turkey at latitude $39.9^{\circ} \mathrm{N}$ and longitude $32.9^{\circ} \mathrm{E}$ which has $\mathrm{Csb}$ climate zone under Köppen-Geiger Climate Classification [19]. Based on the data between 1927 and 2019, the average annual outdoor temperature of Ankara is $12{ }^{\circ} \mathrm{C}$ [20]. Two office rooms (Office A and B) which have same architectural configurations are selected as a case study (Fig.1).

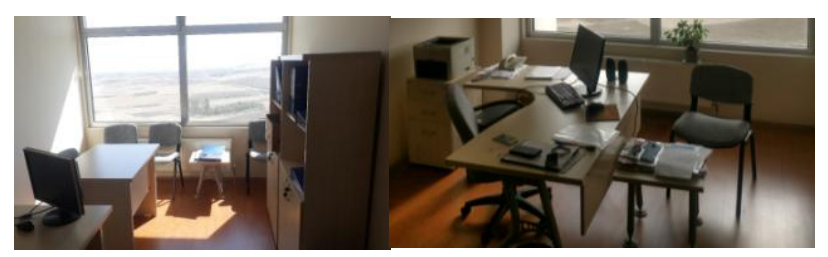

Figure 1. Selected offices for the case study

\section{a) Office A b) Office B}

Each office has a total dimension of $3 \mathrm{~m}$ (width) $\times 5 \mathrm{~m}$ (depth) $\times 2.8 \mathrm{~m}$ (height), one window and one external wall. The offices face the same south direction. The indoor environment of each office is heated/cooled by an air-conditioner which is set $22^{\circ} \mathrm{C}$ for winter and summer seasons (Fig.2). The reason of setting a constant temperature is to ensure optimal productivity and efficiency of occupants in office environments [2122].A mobile air-conditioner is selected as an HVAC system since it can be easily demodulated and 
controlled by an IR receiver and transmitter, respectively. The features of the air conditioner is given in Table 1.

Table 1. Specification of air-conditioners

\begin{tabular}{|l|l|}
\hline Heating & $8800 \mathrm{Btu} / \mathrm{h}$ \\
\hline Cooling & $9000 \mathrm{Btu} / \mathrm{h}$ \\
\hline Remote Controller Unit & $38 \mathrm{kHz}$ \\
\hline Energy Supply & $230 \mathrm{Volt}$ \\
\hline COP-heating & 3.10 \\
\hline COP-cooling & 2.91 \\
\hline
\end{tabular}

Each office is occupied by a male occupant from 08.30 a.m to $12: 30$ p.m and 01:30 p.m to $05: 00$ p.m during weekdays. The occupants are requested to use their offices with same usage intensity and ventilation schedule while no visitors/guests are allowed in order to avoid increased temperature in offices due to the internal heat gains during the measurements. The personal parameters of the occupants are given in Table 2.

Table 2. Physiological parameters of the occupants

\begin{tabular}{|l|c|c|}
\hline & Office A & Office B \\
\hline Gender & \multicolumn{2}{|c|}{ Male } \\
\hline Age & 34 & 34 \\
\hline Body Mass Index (kg) & 22.7 & 22.9 \\
\hline
\end{tabular}

The air-conditioners are kept open only during office hours. The airtightness of the envelope is assumed as $0.5 \mathrm{ACH}$ (air change per hour) for each offices according to the standard value for natural ventilated building in ASHRAE 55 [1]. The overall heat transfer coefficient (Uvalue) of the external wall is calculated as $0.91 \mathrm{~W} / \mathrm{m}^{2} \mathrm{~K}$ while roof and ground is assumed as adiabatic since there exists other air-conditioned office rooms. In addition, U-values of window and door are 1.45 and 1.7 $\mathrm{W} / \mathrm{m}^{2} \mathrm{~K}$, respectively. The radiators, computers and appliances such as photocopiers which exist in the office rooms are kept closed during the experiments in order to avoid internal heat sources.

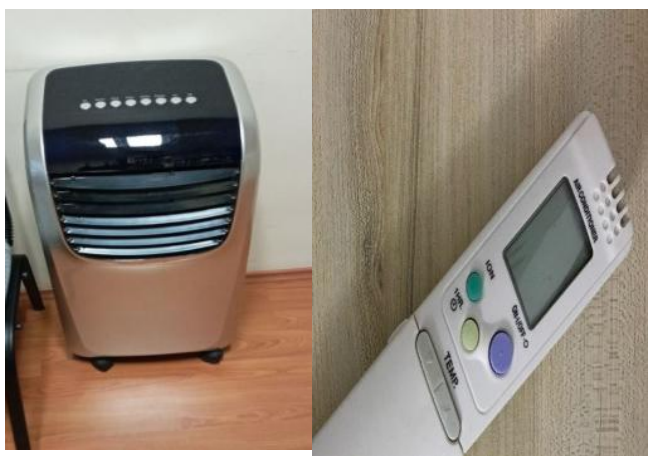

Figure 2. Selected HVAC system for the office rooms

\section{Materials and Methods}

The overall process of methodology includes three sections; development of the control methods for HVAC systems, measurement campaign and comparison of the results in terms of thermal comfort and energy consumption. Figure 3 depicts the flow chart of the methodology used in the study.

\begin{tabular}{|c|c|}
\hline \multicolumn{2}{|c|}{$\begin{array}{l}\text { Developing Control Method } \\
\text { 1. Demodulate IR codes of HVAC system } \\
\text { 2. Develop software and mobile application for } T_{i} \text { and } \\
\text { OT-driven controllers } \\
\text { 3. Constructs wireless sensor network } \\
\text { 4. Re-send IR Codes to adjust set-temperature of HVAC } \\
\text { system }\end{array}$} \\
\hline $\begin{array}{l}\text { Measurement Campaign } \\
\quad \text { (Office A) } \\
\text { 1. Measure } T_{i} \text { in Office A } \\
\text { 2. Hold } T_{i} \text { at } 22^{\circ} \mathrm{C} \text { in Office A } \\
\text { 3. Obtain thermal comfort } \\
\text { for subjective } \\
\text { measurements via mobile } \\
\text { application } \\
\text { 4. Measure energy } \\
\text { consumption of HVAC } \\
\text { system }\end{array}$ & $\begin{array}{l}\begin{array}{c}\text { Measurement } \\
\text { Campaign } \\
\text { (Office B) }\end{array} \\
\text { 1. Measure OT in Office } \\
\text { B } \\
\text { 2. Hold OT at } 22^{\circ} \mathrm{C} \text { in } \\
\text { Office } B \\
\text { 3. Obtain thermal } \\
\text { comfort for subjective } \\
\text { measurements via } \\
\text { mobile application } \\
\text { 4. Measure energy } \\
\text { consumption of HVAC } \\
\text { system }\end{array}$ \\
\hline \multicolumn{2}{|c|}{ Comparison of the Results } \\
\hline
\end{tabular}

Figure 3. Overview of the methodology

\subsection{Developing control methods}

Control methods of the HVAC systems lay on simple PID control techniques which regulate the set-temperature by $\mathrm{T}_{\mathrm{i}}$ and OT for Office $\mathrm{A}$ and $\mathrm{B}$, respectively. PID controllers calculate the difference between the desired temperature and set-temperature and operate the HVAC system according to an error function. The settemperatures of each HVAC system are kept at $22^{\circ} \mathrm{C}$. However, set-temperature of Office $A$ is regulated according to $T_{i}$ measurements while OT is regulated for the set-temperature of Office B. For instance, for Office $A$, if the $T_{i}$ decreases below $22{ }^{\circ} \mathrm{C}$, the developed controller opens the HVAC system via sending IR signals. Similarly, if $\mathrm{T}_{\mathrm{i}}$ increases above $22{ }^{\circ} \mathrm{C}$, the controller closes the HVAC system. The same procedure is valid for Office $B$, however, this time, the system is operated according to OT measurements. Finally, it is worth to note that the software of controllers are written in C-programming language.

Two controllers are developed for the study. Controller consists of an IR receiver to demodulate IR codes of HVAC system, an IR transmitter to send signals to HVAC system, two microcontrollers to achieve $T_{i}$ and OT measurements and control HVAC system according to the results and a Wi-Fi Module to communicate among 
OT and $\mathrm{T}_{\mathrm{i}}$ sensors, controller and mobile application, wirelessly (Fig.4).

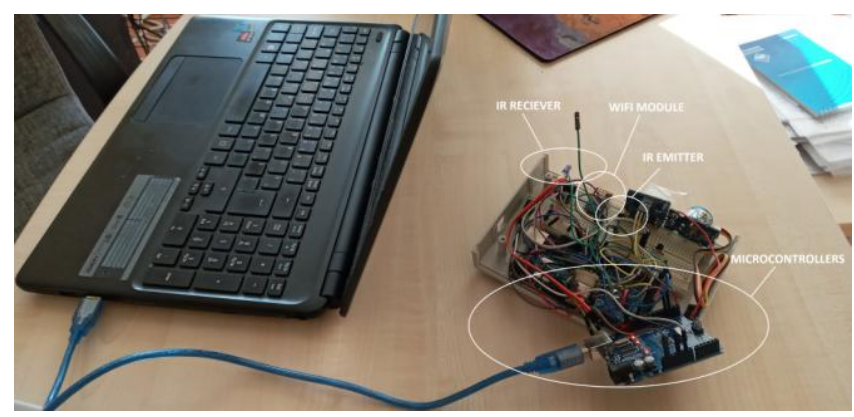

Figure 4. Hardware of controllers

\subsection{Measurement campaigns}

The developed controllers are applied in two office rooms from August 1st, 2019 to January 21st, 2020 including cooling and heating modes. Afterwards, an experimental study is conducted to understand the difference between $\mathrm{T}_{\mathrm{i}}$-driven and OT-driven HVAC systems in terms of thermal comfort and energy consumption. ISO 7730 standard [2], which is based on ASHRAE 55 [1], is used to measure indoor environment of offices. $\mathrm{T}_{0}, \mathrm{~T}_{\mathrm{i}}$ and OT are measured for each offices. However, the developed controllers use only $T_{i}$ and OT values to regulate HVAC systems for Office $A$ and $B$, respectively. As a first step, the set-temperature of HVAC systems (air-conditioners in this study) is adjusted to $22{ }^{\circ} \mathrm{C}$ covering heating and cooling seasons. Then, a DHT22 sensor, which measures indoor air temperature, is used to measure $T_{i}$ for Office A (Fig.5). The measurement results are processed in the controller and controller operates the HVAC system by regulating $T_{i}$.

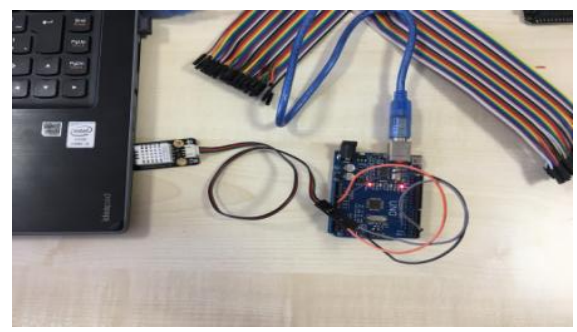

Figure 5. Objective measurements for Office A

Similarly, for Office B, a well-calibrated globethermometer, which is developed by the author, measures OT, continuously (Fig.6). Since there is no mechanical ventilation in the office rooms, OT is taken as in Equation 1 according to ASHRAE 55 [1] for $\mathrm{v}_{\mathrm{a}}$ at or below $0.1 \mathrm{~m} / \mathrm{s}$.

$$
\mathrm{OT}=\left(\mathrm{T}_{\mathrm{i}}+\mathrm{MRT}\right) / 2
$$

MRT is calculated by using a k-type thermometer which is located at the center of a hollow copper-sphere of the developed globe thermometer. The temperature obtained from globe thermometer $\left(\mathrm{T}_{\mathrm{g}}\right)$ is then recorded on a server and MRT is calculated automatically by the controller as in Equation 2 [23]. The emissivity $(\epsilon)$ of the matt-black copper sphere is taken as 0.95 while diameter (D) of the sphere is $150 \mathrm{~mm}$.

$$
\operatorname{MRT}=\left[\left(T_{g}-T_{i}\right)^{4} \times \frac{0.25 \times 10^{8}}{\epsilon} \times\left(\frac{\left|T_{g}-T_{i}\right|}{D}\right)^{\frac{1}{4}}\left(T_{g}-T_{i}\right)\right]^{\frac{1}{4}}-273
$$

The results of the developed sensors are reliable when they provide that they are calibrated. To this aim, developed globe thermometer is calibrated with a wellknown commercial globe-thermometer.

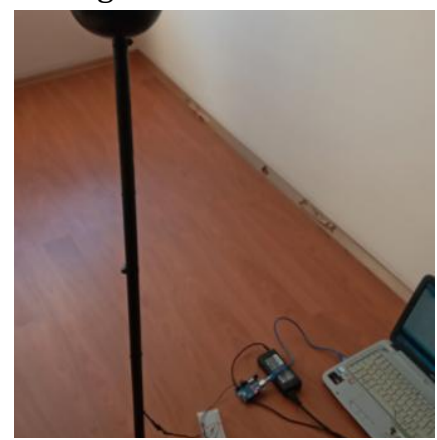

Figure 6. Developed globe thermometer to measure OT for Office B

It is worth to note that all measurement sensors are deployed at same location and $1.1 \mathrm{~m}$ height from the floor according to ASHRAE 55 [1]. The metabolic rate of the occupants is chosen to be 1 met $\left(\mathrm{M}=58 \mathrm{~W} / \mathrm{m}^{2}\right)$ corresponding to normal work when sitting in an office [1]. On the other hand, subjective measurement includes obtaining Thermal Sensation Vote (TSV) of the occupants. Occupants are selected at the same age and similar body mass indices in order to avoid disturbances on TSV. An Android-based smartphone mobile application is developed for the subjective measurement (Fig.7). In the first interface, the application asks the location of the occupant to understand which thermal preference belongs to which offices. Then, the occupants are required to rate their thermal sensations by using well-known ASHRAE seven point scale [1]. The mobile application is used by the occupants with 10 mins-interval during the office hours. 


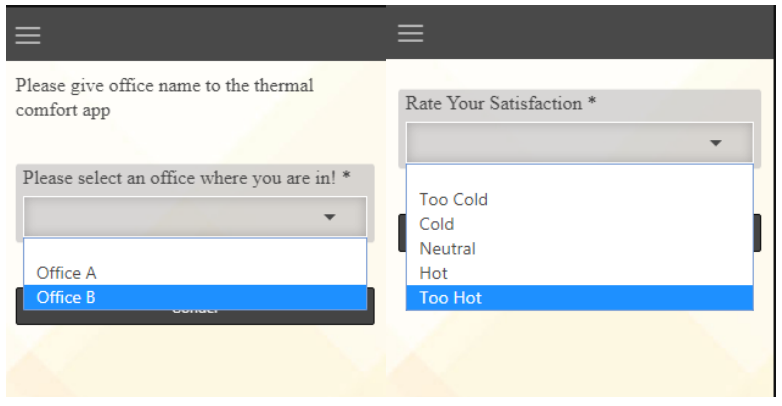

Figure 7. Screenshots of developed mobile application for the study

The energy consumption of the air-conditioners is measured in kWh by a three phase-power analyzer. The list of the used instruments and their accuracy are given in Table 3. Finally, it is worth to note that the objective and subjective measurement results are stored in a web-server and mathematical operations are made by microcontrollers which exist in both office rooms.

Table 3. Specifications of the instruments

\begin{tabular}{|c|c|c|}
\hline Instrument & $\begin{array}{c}\text { Measured } \\
\text { parameter }\end{array}$ & Accuracy \\
\hline DHT 22 & $\mathrm{T}_{\mathrm{i}}, \mathrm{T}_{\mathrm{o}}$ & $<1^{\circ} \mathrm{C}$ \\
\hline $\begin{array}{c}\text { Globe- } \\
\text { Thermometer } \\
\text { developed by } \\
\text { the author) }\end{array}$ & OT & $<1^{\circ} \mathrm{C}$ \\
\hline $\begin{array}{c}\text { Extech Power } \\
\text { Analyzer }\end{array}$ & $\begin{array}{c}\text { Energy } \\
\text { consumption in } \\
\mathrm{kWh}\end{array}$ & $\begin{array}{c} \pm 2 \% \text { for } \\
\mathrm{kWh}\end{array}$ \\
\hline
\end{tabular}

\subsection{Comparison of the results}

The results are compared in two ways; thermal comfort and energy consumption. Energy consumption of the HVAC systems is measured via power analyzers while TSV of the occupants is obtained with the help of mobile application. The aim of the comparison of $\mathrm{T}_{\mathrm{i}}$ and OTdriven HVAC systems is to show which method is efficient in terms of thermal comfort and energy.

\section{Results and Discussions}

As indicated in Section 3.2., objective parameters $\left(\mathrm{T}_{\mathrm{i}}, \mathrm{T}_{\mathrm{o}}\right.$ and OT) and subjective parameter (TSV) are measured and stored between August 1st, 2019 and January 21 ${ }^{\text {st }}$, 2020 including summer and winter seasons (Table 4). It is worth to note that October is included in cooling season due to the above-average temperature throughout the month.

Table 4. Dates for experiments

\begin{tabular}{|l|l|}
\hline Mode & Experiment dates \\
\hline Cooling & August $1^{\text {st }}, 2019$ - October $31^{\text {st }}, 2019$ \\
\hline Heating & November $1^{\text {st }}, 2019$ - January $21^{\text {st }}, 2020$ \\
\hline
\end{tabular}

Table 5 shows total measurement days, $\mathrm{T}_{0}, \mathrm{~T}_{\mathrm{i}}$ and OT values for both offices including heating and cooling modes.

Table 5. Measured $\mathrm{T}_{\mathrm{o}}, \mathrm{T}_{\mathrm{i}}$ and OT values in measurement period

\begin{tabular}{|c|c|c|c|c|}
\hline & & & Office A & Office B \\
\hline \multirow{2}{*}{$\begin{array}{l}\text { Experiment } \\
\text { Days }\end{array}$} & \multicolumn{2}{|c|}{ Heating } & \multicolumn{2}{|l|}{60} \\
\hline & \multicolumn{2}{|c|}{ Cooling } & \multicolumn{2}{|l|}{71} \\
\hline \multirow{6}{*}{$\mathrm{T}_{\mathrm{o}}\left({ }^{\mathrm{o}} \mathrm{C}\right)$} & \multirow{3}{*}{ 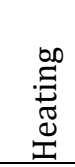 } & Min & \multicolumn{2}{|l|}{-1.5} \\
\hline & & Max & \multicolumn{2}{|l|}{20.9} \\
\hline & & Average & \multicolumn{2}{|l|}{3.5} \\
\hline & \multirow{3}{*}{ مٍٍْ: } & Min & \multicolumn{2}{|l|}{20.4} \\
\hline & & Max & \multicolumn{2}{|l|}{26.4} \\
\hline & & Average & \multicolumn{2}{|l|}{22.8} \\
\hline \multirow{6}{*}{$\mathrm{T}_{\mathrm{i}}\left({ }^{\circ} \mathrm{C}\right)$} & \multirow{3}{*}{ 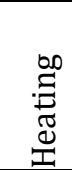 } & Min & 21 & 21.4 \\
\hline & & Max & 22 & 23.1 \\
\hline & & Average & 21.4 & 22.4 \\
\hline & \multirow{3}{*}{ مْ } & Min & 21.8 & 21.4 \\
\hline & & Max & 22.5 & 23.6 \\
\hline & & Average & 22 & 22.2 \\
\hline \multirow{6}{*}{$\mathrm{OT}\left({ }^{\circ} \mathrm{C}\right)$} & \multirow{3}{*}{ 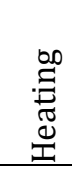 } & Min & 16.1 & 21.2 \\
\hline & & Max & 21.1 & 22 \\
\hline & & Average & 17.4 & 21.6 \\
\hline & \multirow{3}{*}{ مْ } & Min & 21.4 & 21.9 \\
\hline & & Max & 24.5 & 22.4 \\
\hline & & Average & 22.6 & 22 \\
\hline
\end{tabular}

Table 5 indicates that $\mathrm{T}_{\mathrm{o}}$ values vary between -1.5 and $26.4^{\circ} \mathrm{C}$. In addition, $\mathrm{T}_{\mathrm{i}}$ and $\mathrm{OT}$ are highly affected by $\mathrm{T}_{\mathrm{o}}$ which leads more energy consumption to reach settemperature for both controllers. Figure 8 depicts trends of daily average $\mathrm{T}_{\mathrm{i}}, \mathrm{T}_{\mathrm{o}}$, OT and TSV values for Office A. It is worth to remind that the black lines show TSV values of the occupant.

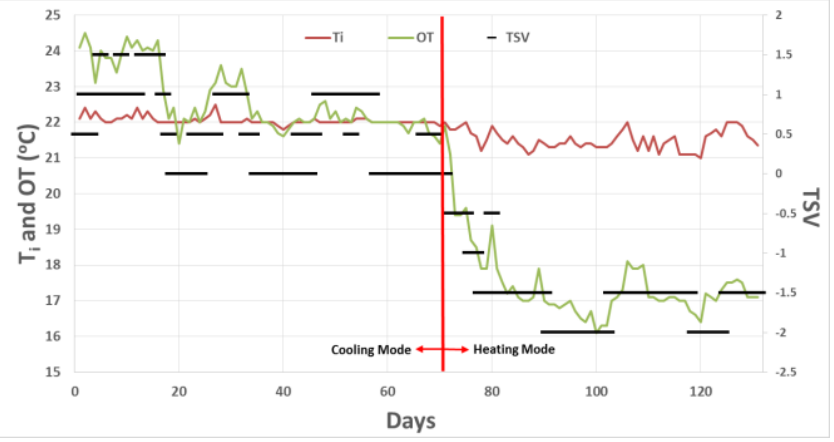

Figure 8. Measurement results for Office A 


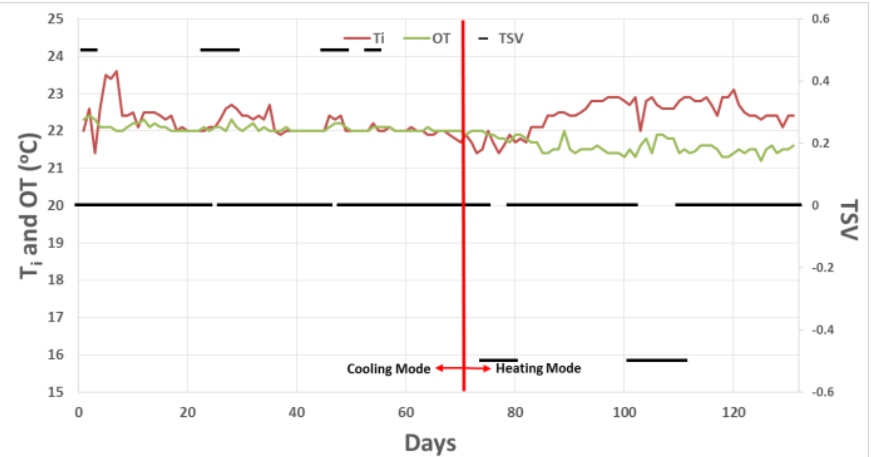

Figure 9. Measurement results for Office B

The TSV values of the occupants are obtained via mobile application. Figure 8 and 9 also state comparison of TSV for two control methods. The TSV values are almost zero for OT-driven HVAC system, however, the range of TSV varies between -2 and 1.5 for $\mathrm{T}_{\mathrm{i}}$-driven HVAC system. In other words, occupant feels neutral on $82 \%$ of total days while OT-driven HVAC system is operated. This value is merely $26 \%$ for $\mathrm{T}_{\mathrm{i}}$-driven HVAC system.

Figure 10 compares energy consumptions of two different controllers. OT-driven HVAC system consumes $2.4 \%$ more energy compared to $\mathrm{T}_{\mathrm{i}}$-driven HVAC system. Total energy consumption for 131 days-experiment period is $526.8 \mathrm{kWh}$ and $539.6 \mathrm{kWh}$ for $\mathrm{T}_{\mathrm{i}}$ and OTdriven HVAC systems, respectively. However, it is worth to remind that occupants feel neutral in OT-driven HVAC system.

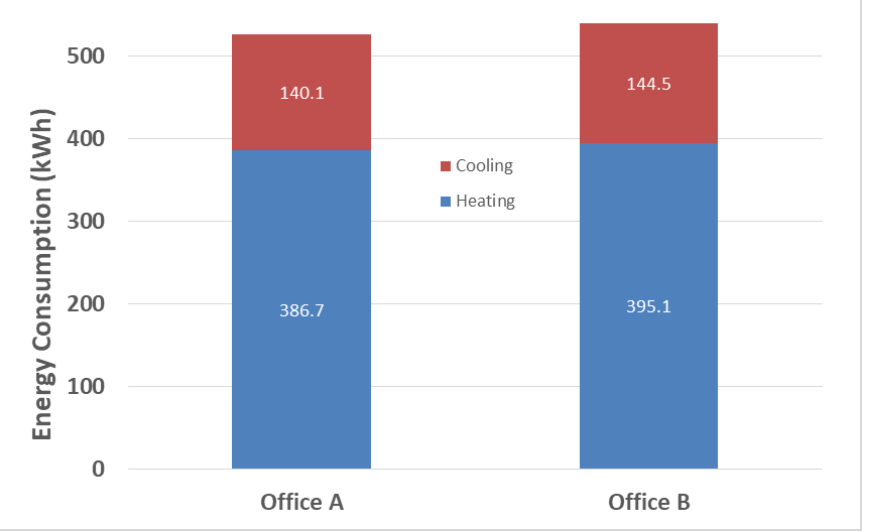

Figure 10. Comparison of energy consumption of OT and $\mathrm{T}_{\mathrm{i}}$-driven HVAC systems

The reason of the increase in energy consumption of OT-driven HVAC system could be temperature differences in different zones of same office. For instance, the OT could vary from $\mathrm{T}_{\mathrm{i}}$ in several areas of an office, which receive a lot of radiant heat from building elements such as wall and window. In addition, the OT differs from $\mathrm{T}_{\mathrm{i}}$ in buildings with large windows where temperature of the window are different from measured $\mathrm{T}_{\mathrm{i}}$ [14]. The window to wall ratio of the case office is 3.6 which is a very high ratio that makes greater difference between OT and $\mathrm{T}_{\mathrm{i}}$. Thus, the OT-driven HVAC system consumes slightly more energy from $\mathrm{T}_{\mathrm{i}}$-driven one in order to reach set-temperature.

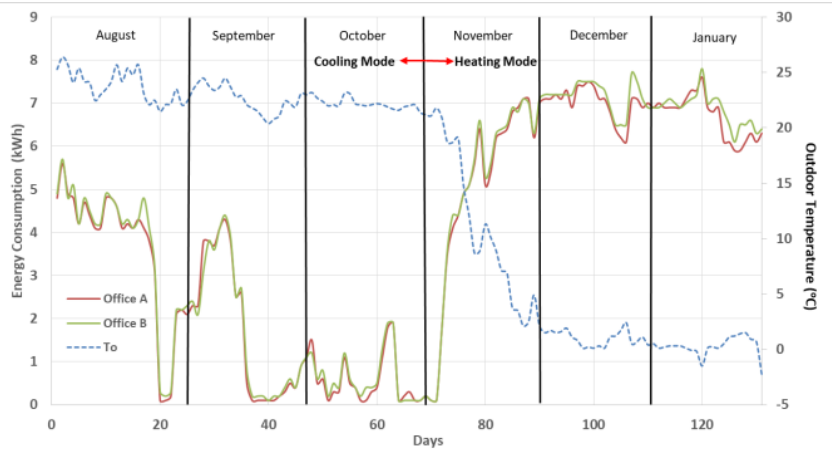

Figure 11. Daily energy consumption of offices

Figure 11 depicts that energy consumption of OT-driven HVAC system is higher than $\mathrm{T}_{\mathrm{i}}$-driven HVAC system in the heating mode. This could be the reason of the cooler temperature of walls than $T_{i}$ due to the cold weather in Ankara. The average values of $\mathrm{T}_{\mathrm{i}}$ and OT for both offices are lower than their set-temperatures (Table 5). This result increases energy consumption for OT-driven HVAC system in heating season.

The general findings of the study can be summarized as the following:

1. Occupant mostly feels neutral in OT-driven HVAC system.

2. TSV value is zero only $26 \%$ of total measurement days in $\mathrm{T}_{\mathrm{i}}$-driven HVAC system. The reason could be the temperature differences of walls and windows from $\mathrm{T}_{\mathrm{i}}$ which make occupant to feel uncomfortable.

3. OT-driven HVAC system consumes more energy. However, considering occupant feels more comfortable, the low energy saving of $\mathrm{T}_{\mathrm{i}^{-}}$ driven HVAC system (2.4\%) is negligible.

The next section provides further results regarding the uncertainty analysis of the measurements.

\subsection{Uncertainty Analysis}

Uncertainty analysis relies on Monte-Carlo method which depends on the measurement errors [24]. Therefore, the analysis is performed by assuming measurement results with mean values while minimum and maximum values are obtained from the accuracy of the measurement devices for every measurement. Table 6 depicts the analysis results in terms of energy consumption.

Table 6. Comparison of energy consumption with Monte-Carlo method

\begin{tabular}{|c|c|c|c|}
\hline Office Type & $\begin{array}{c}\text { Maximum } \\
(\mathrm{kWh})\end{array}$ & $\begin{array}{c}\text { Average } \\
(\mathrm{kWh})\end{array}$ & $\begin{array}{c}\text { Minimum } \\
(\mathrm{kWh})\end{array}$ \\
\hline Office A & 547.1 & 526.8 & 501.6 \\
\hline Office B & 549.3 & 539.6 & 529.1 \\
\hline
\end{tabular}

In the case of an experiment with measurement errors, OT-driven HVAC system still consumes more energy than $\mathrm{T}_{\mathrm{i}}$-driven HVAC system. However, it is worth to remind that these results could change with lowaccuracy devices. Moreover, in presence of uncertainty 
and modelling errors, Monte-Carlo method seems to facilitate the validation of the measurements to compare two different HVAC systems.

\section{Conclusions}

The purpose of this paper is to compare $\mathrm{T}_{\mathrm{i}}$-driven and OT-driven HVAC systems by means of thermal comfort and energy consumption. Two office rooms, which have exactly same architectural configurations, are selected as a case study. Two different control methods which regulate set-temperatures of HVAC system according to $\mathrm{T}_{\mathrm{i}}$ and OT, respectively, are developed and applied in the office rooms. Each office room is occupied with one male occupant and measurements are conducted during office hours. Objective measurements including $\mathrm{T}_{\mathrm{i}}, \mathrm{T}_{\mathrm{o}}$ and OT are taken via objective sensors while TSV is obtained with the help of a developed mobile application. The results showed that OT-driven HVAC system satisfied better thermal comfort while slightly increasing energy consumption.

In the study, TSV values are obtained from oneoccupant. However, the results could be verified with larger occupancy. Although two occupants with almost same physiological parameters are used in the study, some other parameters such as psychology could affect TSV and energy consumption behaviors.

On the other hand, the case office is relatively small office building. Compared to the larger offices, the temperature of walls or windows have higher effect on thermal comfort of occupants. To this aim, as a future study, the experiments will be conducted in different type of offices with larger occupancy.

\section{References}

[1] ASHRAE 55, Thermal Environment Conditions for Human Occupancy, 2017.

[2] ISO 7730, Moderate Thermal EnvironmentsDetermination of the PMV and PPD indices and Specification of the Conditions for Thermal Comfort, International Standards Organization, 1995.

[3] Fanger, P., Thermal Comfort, Danish Technical Press, Copenhagen, 1970.

[4] Calvino, M., Gennusa, M.L., Morale, M., Rizzo, G. and Scaccianoce, G., "Comparing Different Control Strategies for Indoor Thermal Comfort Aimed at the Evaluation of the Energy Cost Quality of the Building", Journal of Process Control, 24 (6), 703713, 2014.

[5] Oktay, H., Argunhan, Z., Yumrutaş, Y., Işık, M.Z. and Budak, N., "An Investigation of the Influence of Thermophysical Properties of Multilayer Walls and Roofs on the Dynamic Thermal Characteristics", Muğla Journal of Science and Technology, 2 (1), 4854, 2016.

[6] Wu, Z., Li, N., Wargocki, P., Peng, J., Li, J. and Cui, H., "Adaptive Thermal Comfort in Naturally Ventilated
Dormitory Buildings in Changsha, China", Energy and Buildings, 186, 56-70, 2019.

[7] Becchio, C., Corgnati, S.F., Vio, M., Crespi, G., Prendin, L., Ranieri, M. and Vidotto, D., "Toward NZEB by optimizing HVAC system configuration in different climates", Energy Procedia, 140, 115-126, 2017.

[8] Kwok, A.G. and Chun, C., "Thermal Comfort in Japanese Schools", Solar Energy, 74 (3), 245-252, 2003.

[9] Nicol, F. and Humpreys, M., "Derivation of the Adaptive Equations for Thermal Comfort in FreeRunning Buildings in European Standard EN15251", Building and Environment, 45 (1), 11-17, 2010.

[10] Wong, N.H. and Khoo, S.S., "Thermal Comfort in Classrooms in the Tropics", Energy and Buildings, 35 (4), 337-351, 2003.

[11] Atmaca, I., Kaynaklı, Ö. and Yiğit, A., "Effects of Radiant Temperature on Thermal Comfort", Building and Environment, 42 (9), 3210-3220, 2007.

[12] Turhan, C., Simani, S., Zajic, I. and Gökçen Akkurt, G., "Performance Analysis of Data-Driven and Model-based Control Strategies Applied to a Thermal Unit Model", Energies, 10 (1), 67, 2017.

[13] Kusiak, A., Tang, F. and Xu, G., "Multi-objective Optimization of HVAC system with an Evolutionary Computational Algorithm", Energy, 36, 2440-2449, 2011.

[14] Jain, V., Garg, V., Mathur, J. and Dhaka, J.,"Effect of Operative Temperature Based Thermostat Control as Compared to Air Temperature Based Control on Energy Consumption in Highly Glazed Buildings", Proceedings of Building Simulation, 1, 2687-2695, 2011.

[15] Olesen, B.W., Wang, H., Kazancl, O.B. and Coakley, D., "The Effect of Room Temperature Control by Airor Operative Temperature on Thermal Comfort and Energy Use" Proceedings of Building Simulation, 1, 18, 2019.

[16] Wang, H., Olesen, B.W. and Kazancl, O.B., "Using Thermostats for Indoor Climate Control in Offices: The Effect on Thermal Comfort and Heating/Cooling Energy Use, Energy and Buildings, 188, 71-83, 2019.

[17] Niu, J.I. and Burnett, J., "Integrating Radiant/ Operative Temperature Controls into Building Energy Simulations", ASHRAE Transactions, 104 (2), 210-217, 1998.

[18] Turhan, C. and Gökçen Akkurt, G., "Assessment of Thermal Comfort Preferences in Mediterranean Climate: A University Office Building Case", Thermal Science, 22 (5), 2177-2187, 2018.

[19] Köppen-Geiger Climate Classification, 2009. Retrieved March 3, from http://koeppen-geiger.vuwien.ac.at/

[20] Turkish State Meteorological Service, 2019.

Retrieved December 3, from https://www.mgm.gov.tr/veridegerlendirme/il-veilceler-istatistik.aspx.

[21] Seppänen, O., Fisk, W.J., Lei, Q.H., "Effect of temperature on task performance in office", 
Lawrence Berkeley National Laboratory, Report No: LBNL - 60946, July, 2006.

[22] World Health Organization, Indoor environment: health aspects of air quality, thermal environment, light and noise, 1990.

[23] ISO 7726, Ergonomics of the Thermal Environment-Instruments for Measuring Physical Quantities, 1998.
[24] Rugen, P. and Callahan, B., "An overview of Monte Carlo-a fifty year perspective", Human and Ecological Risk Assessment, 2, 671-680, 1996.

Y.Wang, X. Meng, L. Zhang, Y. Liu, E. Long, Angle factor calculation for the thermal radiation environment of the human body, 